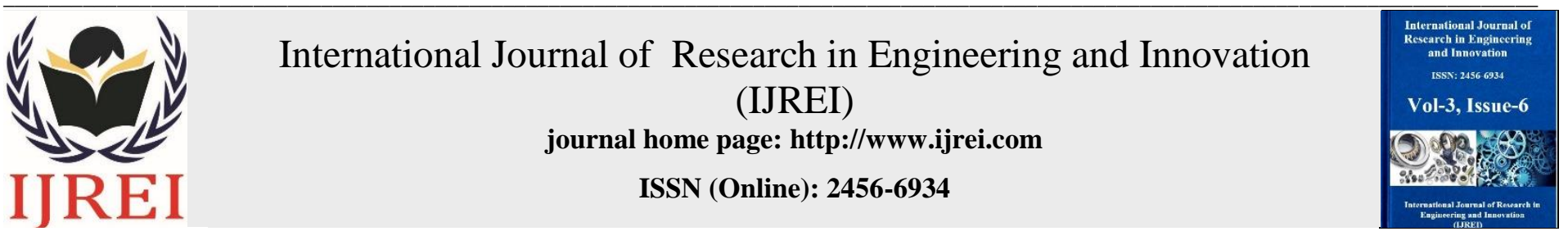

\title{
Opportunities and challenges of the use of mobile phone technology in teaching and learning in Nigeria- A Review
}

\section{Edeh Michael Onyema}

Department of Mathematics and Computer Science Coal City University, Enugu, Nigeria

\begin{abstract}
The use of mobile phones and other related portable technologies in classrooms have become an important part of the teaching and learning process. This is due to their potentials to inspire students' learning interest and support the achievement of set teaching learning objectives. Many students are closely attached to their mobile phones which make it easier for educators to integrate it in pedagogy. The use of mobile phones in classrooms enables students to participate more actively in a learning process, and to engage and interact meaningfully with the teacher both within and outside the school walls. There are millions of students using mobile phones in Nigeria, but the pedagogical benefits of this technology are being ignored by most schools in Nigeria. The use of mobile phones in classrooms is not encouraged in most learning institutions in Nigeria despite its widespread. However, considering the growing trend in education which requires the use of modern learning technologies, there is need for stakeholders in education sector in Nigeria to embrace the "Bring Your Own Technology (BYOT)" initiative which is currently being adopted by many countries around the world to improve the quality of teaching and learning. The study examines the opportunities and challenges of using mobile phone technology in teaching and learning in Nigeria. The results show that the use of mobile phone technology in pedagogy leads to innovations and creativity in teaching and learning. While other associated benefits includes: Distributed and M-Learning, Motivation, Availability/Accessibility, Collaborative/Cooperative Learning, and Student teacher relationship. Also, issues such as Digital divide; socio-cultural factors, abuse, cost, network issues, institutional, economic and infrastructural factors, and resistance were identified as some of the challenges. The study concludes that the use of mobile phone technology in teaching and learning can improve the creative and problem solving skills of students.

C2019 ijrei.com. All rights reserved
\end{abstract}

Keywords: Mobile Phone, Smartphone, Android Phones, Teaching Learning, M learning, BYOT

\section{Introduction}

Emerging technologies such as mobile computing and tablet computing has brought tremendous transformational changes to Teaching and learning across the globe. Education is now moving towards technology-based learning which allows the adoption and integration of different learning technologies in the teaching learning process. [1] reported that the use of "story telling digital courses produced like T.V Series," have increased students' attention and ability to remember formulas and understand lessons. The relationship between education and technology is growing stronger, and many educational institutions now introduce the concept of "Bring Your Own Device (BYOD)". BYOD is a technology model where students bring a personally owned device to school for the purpose of learning [2], and [3]. While some have modified it as "Bring Your Own Technology (BYOT)', the motive remains the same, which is to encourage creativity in learning, and more students' involvement in the learning process using technology.

Society is rapidly moving from desktop and laptop computing to mobile devices, such as smartphones [4]. The penetration of mobile phone technology is unimaginable to the extent that it has provoked series of researches on how it can be integrated into the teaching and learning process. Studies have shown that mobile phones could be an effective tool for learning enhancement. [5] state that technological advancements, coupled with the widespread availability and relatively low cost of mobile devices, represent a tremendous opportunity to leverage the power and ubiquity of mobile technologies to enhance learning and extend educational opportunities. The portability and affordability of 
mobile phones has increased its spread and availability in most communities in Nigeria particularly among adolescents, students and even the elderly. UNESCO report in 2013 stated that mobile technologies are commonly found nowadays even in areas where schools, books, and computers are scarce. Due to the fall in prices of mobile phones in particular, many people, even in impoverished areas, can afford and know how to use mobile devices [6]. [7] Opined that there has never been any technological advancement in entire history that has been so available to civil societies as mobile communication [7]. Bill Gates cited in [8] argued that cell phones, not laptop computers, hold the most promise for the spread of one-to-one computing, particularly for students with limited resources and especially for students from developing nations. Mobile phones can increase the scope of education in any community considering the spread. More so, several studies have been carried out on the use of mobile phones for teaching and learning [9-13]. Some of the results show that the use of mobile phones during lessons has positive effects on learning outcomes [14]. The application of mobile phones makes available data collection and processing of incoming information even during lessons emphasizing a technological hybrid tool as a supplementary instrument in teaching [15]. It is no doubt that mobile phones and other related gadgets have the capability to change lives [16]. The use of mobile phones in classroom can influence the performance of students in a given course. It can make learning to be more interactive, productive and entertaining. [17] Opined that a number of positive pedagogical advantages seem to be salient, and number of schools and universities rebuff the use of mobile phones in classrooms forcing teachers to stick to traditional teaching methods. The literature on the pedagogical benefits of mobile technology particularly in Nigeria is scarce. Consequently, the present study examines the challenges and the potential opportunities offered by use of mobile phone technology in teaching and learning in Nigeria, with a view to generate new knowledge, validate existing knowledge, and to draw more attention on the pedagogical potentials of mobile phone technology.

\section{Review of related literature}

The paradigm shift in education towards equipping people to use knowledge in inventive ways, new contexts and combinations opened the door for technology to be infused into 21 st century learning [18]. The emergent of mobile computing and tablet computing has increased the curiosity of many people about the potentials of mobile phone technology in education. Mobile phone devices vary in sizes and function but they share many similar qualities particularly as it relates to portability, mobility and affordability. The use of mobile phones could modernize approach to learning from one sided teacher centered to a more impactful student centered method which allows the students to learn more effectively, and teachers to adopt different styles. The findings of a study conducted by [19] on selected teaching staff and students, show that majority of the teaching staff use mobile phones for communicating with colleagues and students on academic issues, and also to access instructional materials from the internet.
[16], state that academic staff utilizes mobile phones (Smartphone) as a means for knowledge sharing. The results of a study conducted by [20] on 300 students in a polytechnic in Ghana, revealed that $82 \%$ of the students use mobile phone technology to support their coursework. [18], conducted a study to investigate the initiative of students bringing their own technology devices into New Zealand Secondary Schools. The result from the study shows that the technology initiative was constrained by change management and student management while the biggest success was noted as a shift to student centered learning. The findings of a study conducted by [21] on "the role of mobile technologies in the teaching/learning process improvement in Portugal" shows that mobile technologies bring motivation and personalization to the teaching learning process leading to greater participation. [4] Conducted a study on "Teaching Chemistry Using Student-Created Videos and Photo Blogs Accessed with Smartphones and Two-Dimensional Barcodes". The result show that students were able to create multimedia content that can be used by future students which make learning more meaningful, and increased their interests in developing projects that are factual and also creative.

[22], conducted a study on "Integrating Mobile Phones into Science Teaching to Help Students Develop a Procedure to Evaluate the Corrosion Rate of Iron in Simulated Seawater". The result revealed that the use of mobile phones was very helpful as it made learning more inviting and meaningful. [23] conducted a study on "Student Impressions of Academic Cell Phone Use in the Classroom" to assess the perspective of students regarding the use of cell phones as academic tools in the classroom, The result revealed that students felt that cell phones helped their learning, encouraged their enjoyment of the class, improved their success in the course, and marginally increased their attendance [23]. [24], states that a class where mobile technologies are not used would be completely uninteresting considering the role it plays in the daily lives of teenagers. The use of mobile technologies in the classroom provides a closer relationship between teacher and student which leads to a joint and more active learning [21]. However, mobile phone technology is underused for pedagogy in Nigeria. Consequently, the need to provide an updated understanding of the opportunities of using mobile phone technology in pedagogy in Nigeria visa-avis the need to get the attentions of stakeholders to tackle the challenges hindering the use of mobile phones and other portable technologies in teaching and learning in Nigeria forms the motivation for the present study.

\section{Mobile phone technology in teaching and learning}

The use of mobile phone and other portable technologies offers enormous opportunities for teaching learning. As the demand for use of more educational technologies increase, mobile phone technology would increasingly become significant in teaching and learning. [22], states that mobile phones equipped with good built-in cameras have become an essential part of everyday lives of students and educators. Evidence has shown that many learning institutions are making effort to implement technology in their teaching learning arrangements. For instance, Coal City University Nigeria, has made it mandatory for all her students to bring in their laptops and other recommended learning mobile 
devices for teaching and learning activities. Also all classrooms in the school are fully equipped with standard projectors to enhance students' learning and participation. There are several types of mobile phone technology ranging from Smartphones; Android phones, I-phones, tablets, and Window phones just to mention but a few. All of these mobile phones have the potential to improve teaching and learning if properly harnessed.

[25], stated that mobile phones have a wide range of educational attributes, such as spontaneity, informality, portability, personalization, ubiquity, pervasiveness and the functions such as voice, text, video, radio, and the internet. Application of mobile technologies in education is becoming a norm for most learning institutions particularly in developed countries. Mobile (cell) phones have become ubiquitous in society, but they are typically seen as a problem in the classroom and can help students access and take ownership of knowledge [23]. Some of the essential benefits mobile phone technology in teaching and learning are discussed below:

\subsection{Mobile Learning (M-learning)}

M-learning involves the integration, application, deployment and usage of portable mobile devices to aid teaching and learning. [26], defines mobile learning as the field of study that analyzes how mobile devices can contribute to learning. Mobile learning devices varies in forms, function, capabilities and architecture, but they perform similar basic functions associated with mobile technologies including the ability to create, edit store and share images, documents and other contents in different formats. According to [5], mobile-learning takes place when a student uses portable devices, such as smart phones, notebooks or tablets, or handheld gaming devices, to access learning materials and systems, create content and interact with other students, teachers, learning systems and the world around them. UNESCO report in 2012, revealed that easy access to mobile phones enhanced the success of some m-learning activities in South Africa [27] Mlearning facilitate learners' continuous access to the latest textbooks, podcasts, videos and multimedia learning experiences sourced from around the world and can choose when and where to work [5].

M-learning is famous for convenience and flexibility in learning particularly in developing countries like Nigeria, where the economy is under recession, and about 15 million children are out of school. While many who are in school struggle to work to fund their education. Mobile learning ensures that all kinds of learners are accommodated especially those with special needs that requires specialized software to be installed in their mobile devices to learn. The use of mobile phones with internet access would enable the "working class" who may still need to further their education but may be constrained by distance and time to fix classes with their teachers at their pace and convenience, and to learn outside the walls of the classroom.

\subsection{Motivation /Facilitation of Students' interest}

The use of mobile phones helps for modification of instructional pattern in classrooms from traditional (teacher-centered) to a more interactive method (learner-centered) which is more motivating for learners. With the use of mobile phones, several applications that support learning can be installed by students which can increase their learning interest in different subject areas.

\subsection{Availability and Accessibility}

The use of mobile phones makes instructional materials to be readily available and accessible at ease. Students can easily surf the internet download or search information regarding a given course or assignments. Furthermore, mobile phones can be used by teachers or educators to share course materials during classes through wireless technologies like Bluetooth, Xender, Flashair, Wifi or social media groups like the whattsap for easier access to students. This eliminates the problem of copying notes manually on the chalk board or running around to make photocopies of course materials.

\subsection{Distributed Learning}

The use of mobile phone technology facilitates distributed and blended learning. It provides opportunity for adoption and practice of different teaching learning styles which can be fixed at any time and place of convenience without the physical presence of the participants. It enhances the success of distance learning, e-learning and even tablet learning thereby taking learning beyond the regular walls of school. The use of mobile phones makes it easier for participants in such classes to easily access internet networks to enhance the success of the process. This goes a long way to remedy some obstacles in learning such as distance, transportation delays, unfavorable weather, physical disabilities, and many more.

\subsection{Collaborative and Cooperative Learning}

The use of mobile phone technologies such as smartphones and tablets has wide spread among students. Hence, it makes it easier for students to form different learning or discussion groups on different platforms like Whatsapp to create knowledge and to share ideas relating to a given course, or assignments. These assist members to also participate actively on group assignments. It also make it easier for students to collaborate and cooperate on given projects.

\subsection{Creativity and Innovation}

Mobile phones are equipped with different applications with various features and capabilities that can easily be applied to create useful innovations. For instance, recently some group of young teenagers in Nigeria shot some sci-fi movies produced with the aid of their smashed mobile phones. The movies went viral, and have now brought the teenagers to limelight. Many students are very close to their mobile phones, and can easily manipulate it to perform different functions. This makes it a valuable tool for innovations and creativity. 


\subsection{Improved Student-Teacher Relationship}

The use of mobile phone technology facilitates healthy communications between teachers and students thereby improving their relationship. This brings about increased interactivity leading to improved students' confidence and trust, thereby making it easier for them to confide in their teachers particularly on issues that bothers on their academic performances or stay on campus. It also assists the teachers to understand students' learning differences and difficulties, and hence adopt suitable methodologies to address them.

\section{Challenges of mobile phones in teaching and learning}

The usage of most technologies is often hampered by different connecting factors which largely depend on the context and place. The use of mobile phones in education is not exempted. While it is evident that it has positive effects in teaching and learning, there are many challenges that hinder the smooth integration of mobile phones and other educational technologies in the teaching and learning process. These challenges vary from country to country, and institutions. [17], stated that mobile phone usage during lessons is unwanted in several countries like Serbia, and many others have banned phones entirely in the classrooms. In Nigeria, students are mostly not allowed to use mobile phones in classrooms. They are either forced to put it on 'silent mode' or totally switch it off during classes, while those who violate this rule are often sanctioned. In Ghana, the use of mobile phones to teach and learn at the primary and secondary school level is not being encouraged at all because students are banned from possessing and using their phones during school hours [20]. This is in contrast to the practice in some advanced countries like U.S, Denmark and New Zealand where the concept of "Bring Your Own (BYOD) are strongly encouraged. The perceptions of some educators and inflexible policies in some educational institutions which often forbid the use of mobile phones in classrooms have made it extremely difficult for teachers and students to maximize the learning potentials of mobile phone technology.

Mobile phones can support different pedagogical tasks, but may also be responsible for problems such as distractions during classes [28]. For [29] ringtones in the classroom, with their variety of musical genres and styles (often amusing) may significantly disturb pedagogical activities as planned by the teacher. Though a silent practice, texting can also draw attentions away from the lesson, as well as be used to send answers of tests or exams. In addition, games, music, videos, photos and access to the internet may compromise students' performance in class [29]. A study conducted by [16] suggests that carrying mobile phones (smartphones) to a workplace has given some negative impacts to the job environment, and it divert academic staffs' focus on work. However, [20] state that teachers, and students make real use of mobile phones to access the internet for teaching and learning, but they also identified poor network service; inadequate knowledge, and faulty mobile phones as major challenge that hamper students' usage of mobile phones to support their learning. Educators cannot know if a technological initiative is successful unless they are able to measure its success [18]. While there will always be skeptics who question the place of cell phones in schools, other technologies have gone through similar tests of practicality and demonstrated usefulness [8]. Thus, there is need for educational institutions to be more flexible in their policies to accommodate genuine ideas that can improve the quality of teaching and learning.

\section{Challenges of mobile phone technology in teaching and learning in Nigeria}

In Nigeria, the use of modern technologies particularly the mobile phone technology in education is hindered by many factors which can be categorized into; Economic and infrastructural, cost, network issues institutional, resistance and socio-cultural factors.

\subsection{Economic and Infrastructural factor}

The educational sector in Nigeria is poorly funded leaving most of the institutions to decay. This could be attributed to the poor state of Nigerian economy and corruption. There are problems of incessant labour strikes arising from delay of workers' salaries and poor infrastructures in as schools. Statistics [30] revealed that between 2000 and 2010, allocation to the education sector by Federal Government in Nigeria was not more than $14 \%$ of the annual budget, which was even low when compared to the allocation of countries such as Kenya, Malawi, Botswana, Angola, Sierra Leone, and South Africa, all in Sub-Saharan Africa. According to [31] a country which is unable to invest in education to develop knowledge and skills of her citizen and utilize them effectively in national economy will be unable to develop anything else. [32], states that teaching and learning take place under unfavorable environment, lacking the basic materials, thus hindering the fulfillment of educational objectives. The poor funding of educational sector in Nigeria has negatively affected the state of infrastructures at schools such as functional internet connections, steady power supply and many more which could have encouraged the use of mobile phones and other educational technologies in schools. Most schools in Nigeria lack the capacity and basic facilities needed to integrate technology in teaching learning. Even the usage of mobile phones is often hindered by poor electricity supply to charge the batteries.

\subsection{Institutional factors}

Some of the educational institutions in Nigeria do not allow the use of mobile phones in classrooms. Some have policies that forbid students from bringing mobile phones to school. This practice is common at the secondary school level particularly in the private schools. The institutional policies regarding the use of mobile phones impede mobile phone incorporation into the teaching and learning process. There is also the problem of lack of internet connections in schools like the open Wifi to facilitate mobile learning activities. There is need for institutions that practice policies that restrict the use of mobile phones to review it in line with current trend in education around the world. 


\subsection{Resistance to Change}

The attitudes of some educators towards professional development or digital literacy skills affect the integration of technologies in the teaching and learning process. Some are so attached to the traditional method of pedagogy which gives them more control, and therefore tend to oppose the use of modern mobile technologies. This kind of attitude has not only affected their skills but also the students they teach. Teachers' reactions towards the usage of mobile phones in classrooms can either encourage or discourage students from using it for academic purposes.

\subsection{Cost}

Although there is a general perception that mobile phones are affordable, however, many students cannot still afford it in Nigeria. This is as a result of the high rate of poverty among the population. About 98 million people are living in extreme poverty in Nigeria. There is also the problem of data cost to access the internet.

\subsection{Network Issues}

The problem of poor network discourages the use of mobile learning in Nigeria. Educators find it difficult to organize mobile learning activities due to poor network infrastructures. There has to be an improvement to enhance the use of mobile phone technology in pedagogy in Nigeria.

\subsection{Mobile Phone Abuse}

Those who oppose the use of mobile phones in Nigeria have argued that it can lead to possible distractions in classrooms. Many have the impressions that if students are allowed to use mobile phones in class, they may not concentrate. This is because they may abuse it for other non-pedagogical activities. There is need for educators to put aside these fears in order not to deprive themselves and students the positive impacts of mobile phone technology in pedagogy.

\subsection{Socio-Cultural factors}

The use of mobile phones in teaching and learning process can be affected by socio-cultural factors such as culture and religion. For instance, some teachers and students have cultural believes that it is disrespectful for a learner to operate his/her mobile phone while being taught or instructed by the teacher. This could be attributed to the use traditional method of teaching where the teachers acts as masters of knowledge unlike the students-centered approach where students are allowed to participate and contribute more in the learning process.

\subsection{Digital Divide}

Some critics of mobile phone technologies in Nigeria are concerned about possible gaps in learning with mobile technologies because students may not have the equal opportunity or amount of resources to acquire the needed mobile phone devices. [4], states that one of the common concerns about using mobile phones (smartphones) in class is the fear that only a few students will have such sophisticated equipment. In Nigeria, students in urban areas seem to have a greater opportunity, and access to mobile technologies compared to their counterparts in the rural areas. Also, students from privileged homes have greater access to mobile technologies than those from disadvantaged backgrounds.

From the aforementioned, there are several challenges that hinder the implementation of mobile phone technology in teaching and learning in Nigeria. These challenges are interconnected, which makes them even more difficult to tackle. However, government, policy makers, educational institutions and other stakeholders have to develop strategies to tackle these emerging challenges in order to optimize the potentials benefits of mobile technologies in pedagogy.

\section{Solutions for smooth usage of mobile phones for pedagogy in Nigeria}

The successful implementation of use of mobile phone and other related educational technologies for pedagogy in Nigeria would require collective efforts of stakeholders in education including parents, government, teachers, policy makers and private organizations. [33], stated that smooth use of mobile technology for learning is dependent on schools having the infrastructure, inspiration, capability and opportunities for innovation. The leadership structure of educational institutions is also critical to implement mobile phone pedagogy. Schools need to be led by persons who understand the importance of digital technology in education [34]. Government has to increase funding for education, and also supervision to ensure transparency in usage of allocated funds. This would go a long way to assist schools particularly public schools to acquire the necessary facilities and educational technologies for effective teaching and learning. There is need for provision of conducive environment that supports the use of technology in education.

Educational institutions should conduct trainings and retraining of staff to improve their digital skills, while adequate IT experts should be engaged to support the use of technologies in schools. Management of schools should provide alternate source of power supply for steady supply of power for digital learning. To bridge the digital gap in learning, efforts should be made to ensure the provision of modern technologies to schools both in rural and urban areas. Students should be motivated to create some of the needed learning technologies to mitigate the problem of cost, in addition to provision of subsidy on mobile learning devices. Education authorities should make it mandatory for educational institutions to adopt and integrate learning technologies such as mobile phones in the teaching and learning process to improve the general quality of education in Nigeria. Also, regulatory bodies like the National University commission (NUC) and National Board for Technical Education (NBTE) should ensure include the availability of technologies in schools as a prerequisite for accreditation or licensing. Furthermore, there is need for steady review of curriculum at all levels of education in line with the changing trends in education. This would assist 
schools and educators to integrate the use of relevant technologies in teaching and learning.

\section{Conclusion}

The study affirms that the use of mobile phone technology is an important pedagogical tool if properly integrated. The findings show that the use of mobile technology for pedagogy is essential to the success of teaching and learning in the $21^{\text {st }}$ century. It also indicates that mobile phone technology enhance the availability and accessibility to large volume of digital learning materials such as Open Online Courses (MOOCs,) and videos to enhance students' understanding of concepts. The use of mobile phones in teaching learning can also encourage creativity and knowledge sharing among learners. However, this can only be effective if the various challenges outlined in this study and many more are properly addressed.

\section{Recommendations}

Based on the findings of the study, the researcher recommend as follows:

- Mobile network service providers should improve their quality of service to enhance the usage of mobile phones for pedagogy.

- Educational institutions should be flexible in their policies to promote the creation and usage of innovative ideas to enhance effectiveness in the achievement of teaching and learning objectives.

- There should be periodic review of curriculum in line with changing trend in education and technology.

- Educators/teachers should develop themselves for easy adaptation to the emerging educational technologies.

- There should an incentive for research on education to enhance innovation and creativity.

- The use of mobile phones for educational activities should be encouraged in classrooms.

\section{References}

[1] Rodrigo, M. (2019). Professor produces Courses like T.V Series. Published at Observatory of Educational Innovation. Accessed from online via. www,observatory.tech.mix. August, 2019.

[2] Alberta Education. (2012). Bring your own device; A guide for schools. Alberta, Canada.

[3] Stavert, B. (2013). Bring your own device (BYOD) in schools. NSW, Australia.

[4] Lucille, B. and Harry, E. P. (2012).Teaching Chemistry Using StudentCreated Videos and Photo Blogs Accessed with Smartphones and TwoDimensional Barcodes. J. of Chem. Edu., 89: 492-496.

[5] Sivakumar, R. (2014). 3G - Mobile Technology in Education. Cognitive Discourses International Multidisciplinary Journal, 2 (1): 49-53.

[6] UNESCO (2013). Policy guidelines for mobile learning [Guidelines]. Paris, France. Retrieved August, 2019, from http://unesdoc.unesco.org/images/0021/002196/219641e.pdf.

[7] Kismihok, G. (2007). The role of mobile learning in European education, Mobile learning report 2007, China, Corvinno Technology Transfer Center Ltd, Hungary, Budapest

[8] Bob, L; Edwin C; and Mervyn,W. (2010). Hang up and learn: Cell phones in the science classroom. TechTrek summer, pp 82-88.

[9] Alfawareh, H.M., and Jusoh, S. (2014). Smartphones usage among university students: Najran University case. International Journal of Academic Research, 6(2): 321-326. https://doi.org/10.7813/20754124.2019/6-2/B.48.

[10] Froese, A. D., Carpenter, C. N., Inman, D. A., Schooley, J. R., Barnes, R. B.,Brecht, P. W., \& Chacon, J. D. (2012). Effects of classroom cell phone use on expected and actual learning. College Student Journal. 46 (2): 323 332.

[11] Rung, A.; Warnke F, Mattheos N.(2014). Investigating the Use of Smartphones for Learning Purposes by Australian Dental Students. Eysenbach G, ed. JMIR mHealth and uHealth. (2): 20. DOI: $10.2196 /$ mhealth. 3120

[12] Elder, A.D. (2013). College students' cell phone use, beliefs, and effects on their Learning, College Student Journal, 47(4): 585-592.

[13] Tindell, D. R., \& Bohlander, R. W. (2012). The use and abuse of cell phones and text messaging in the classroom: A survey of college students. College Teaching, 60(1).1-9. Retrieved from http://www.tandfonline.com, https://doi.org/10.1080/87567555.2019.604802.

[14] Abu-Al-Aish, A., Love, S., \& Hunaiti, Z. (2012). Mathematics Students' Readiness for Mobile Learning, Int. Journal of Mobile and Blended Learning. Brunel University, UK, (p. 1-20)

[15] Naismith, L., Lonsdale, P., Vavoula, G., \& Sharples, M. (2004). Literature Review In Mobile Technologies and Learning, Futurelab University of Birmingham, UK.

[16] Hejab M. Al F. and Shaidah, J. (2017). The Use and Effects of Smartphones in Higher Education. IJIM, 11 (6):106-111.

[17] Körösi, G and Esztelecki, P.(2015). Implementation of Mobile Phones in Education. Original scientific paper,UDK: 371.39: 98-108. DOI:10.17810/2015.08.

[18] Karen, B. (2014). Investigating the Initiative of Students Bringing Their Own Technology Devices into New Zealand Secondary Schools. A thesis submitted in partial fulfilment of the requirements for the degree of Master of Educational Leadership and Management. Unitec Institute of Technology.

[19] Mtega WP, Bernard R, Msungu AC, Sanare R. (2012). Using mobile phones for teaching and learning purposes in higher learning institutions: The case of Sokoine University of Agriculture in Tanzania. InProceedings and report of the 5th Ubuntu Net Alliance annual conference 2012 (pp. 118-129).

[20] Zakaria, I.M.; Fordjour, K. A. and Afriyie, K. R. (2015). Use of Mobile Phones to Support Coursework: Evidence from Wa Polytechnic, Ghana. GJDS, 12(1 \& 2): 195-207.

[21] Maria João Ferreira, Fernando Moreira, Carla Santos Pereira, Natercia Durão (2015). The role of mobile technologies in the teaching/learning process improvement in portugal. Proceedings of ICERI2015 Conference 16th-18th November 2015, Seville, Spain.

[22] Edgar P. M; Mario, R. C; and Luiz, H. S. (2015). Integrating Mobile Phones into Science Teaching To Help Students Develop a Procedure To Evaluate the Corrosion Rate of Iron in Simulated Seawater. J. of Chem. Edu. 92: 1696-1699.

[23] Jack, T. (2013). Student Impressions of Academic Cell Phone Use in the Classroom. Journal of College Science Teaching, 43 (1): 25-29.

[24] Kenny, R. F., Park, C. L., Van Neste-Kenny, J. M. C.; Burton, P., Park, C. L., \& Qayyum, A. (2012). Using Self-Efficacy to Assess the Readiness of Nursing Educators and Students for Mobile Learning. International Review of Research in Open and Distance Learning, 13(3):277-296

[25] Kukulska-Hulme, A., Evans, D. and Traxler, J. (2005) Landscape study on the use of mobile and wireless technologies for teaching and learning in the post-16 sector.

http://www.jisc.ac.uk/whatwedo/programmes/elearninginnovation/outco mes.Accessed August 2019.

[26] Batista, S. C. F. (2011). M-LearnMat: Modelo Pedagógico para Atividades de M-learning em Matemática. Tese, Doutorado em Informática na Educação, Universidade Federal do Rio Grande do Sul (UFRGS), Porto Alegre, RS, Brazil.

[27] UNESCO (2012). Mobile learning for teachers in Africa and the Middle East: Exploring the potentials of mobile technologies to support teachers and improve practices. Available at: unesdoc.unesco.org/images/0021/002163/216358e.pdf.

[28] Silvia, C.F.B. and Gilmara, T.B. (2014). Considerations on the Use of Mobile Phones in Educational Context. Int. Journal on New Trends in Education and Their Implications, 5 (1):1-10. 
[29] Machado, J. L. A. (2012). Celular na escola: o que fazer?. Retrieved August, 2019, from http://cmais.com.br/educacao/celular-na-escola-oque-fazer.

[30] Central Bank of Nigeria (2010). Statistical Bulletin. Abuja, Nigeria: Federal Government Press.

[31] Todaro, S. (2004). Determinants of Student Achievement: New Evidence from San Diego. San Diego: Public Policy Institute of California.

[32] Ahmed, T.M. (2003).Education and National Development in Nigeria. J. Stud. Edu.10:35-46.

[33] Bolstad, R., Glilbert, J., McDowall, S., Bull, A., Boyd, S., \& Hipkins, R. (2012). Supporting future-orientated learning and teaching - a New Zealand perspective. Wellington, New Zealand: New Zealand Council for Educational Research.

[34] Kaye,N.(2012). Inquiry into 21st century learning environments and digital literacy. Wellington, New Zealand: House of Representatives.

\section{Biography}

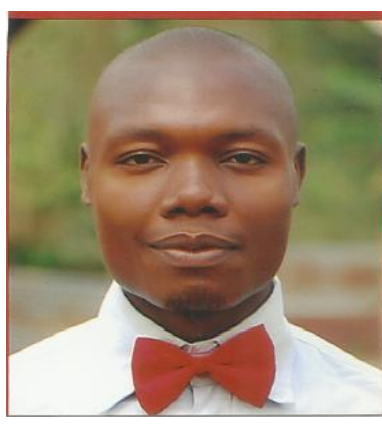

Edeh Michael Onyema is a lecturer of Computer Science at Coal City University at Enugu, Nigeria. He earned a master's degree in Computer Science Education at Tai Solarin University of Education (2017). He has taught Computer Science courses to students and teachers in different higher institutions in Nigeria, and has facilitated multiple professional development programs for students and youths. His research interests include learning technologies, inquiry-based teaching, and IT Security.

Cite this article as: Edeh Michael Onyema, Opportunities and challenges of use of mobile phone technology in teaching and learning in Nigeria- A Review, International Journal of Research in Engineering and Innovation Vol-3, Issue-6 (2019), 352-358, http://doi.org/10.36037/IJREI.2019.3601 